\title{
Evaluation of new genotypes of brinjal (Solanum melongena L.) under tarai condition of Uttarakhand
}

\author{
Arun Singh Chaudhary, S.P. Uniyal and Pooja Pandey \\ Pantnagar-263 145 U. S. Nagar, (Uttarakhand), INDIA \\ *Corresponding author. E-mail: aschaudhari87@gmail.com \\ Received: September 19, 2016; Revised received: April 8, 2017; Accepted: August 25, 2017
}

Department of Vegetable Science, College of Agriculture, G.B. Pant University of Agriculture and Technology,

\begin{abstract}
In order to assess the performance of some new genotypes of brinjal (Solanum melongena L.) under tarai condition of Uttarakhand, an investigation was carried out at Vegetable Research Centre, G. B. Pant University of Agriculture and Technology, Pantnagar, during autumn-winter cropping season of 2012-13. The experiment was laid out in Randomized Complete Block Design with 4 replications and 9 treatments viz. PB-300, PB-301, PB-302, PB-303, PB-304, PB-305, Kashi Tarun, Punjab Sadabahar and Pant Samrat. To have comparative study, growth characters, per cent fruit infested by fruit borer, fruit yield and finally economics were also worked out. The findings revealed that none of the new genotypes in this study could supersede the local checks in respect to yield related attributes, per cent infested fruit by borer and economics. Amongst 6 genotypes and 3 commercial cultivars, variety Kashi Tarun proved the best with respect to fruit yield $(490.73 \mathrm{q} / \mathrm{ha})$ and $\mathrm{B}: \mathrm{C}(2.43)$. It is also less infested by fruit borer. The per cent infested fruit by borer was $7.16 \%$. Variety pant samrat and pant bahar were also considered promising with 385.70 and 369.33 q/ha marketable fruit yield.
\end{abstract}

Keywords: B-C ratio, Solanum melongena L., Marketable yield, Net return

\section{INTRODUCTION}

Brinjal or eggplant is an important vegetable grown worldwide. It is considered a native of India where the major domestication of large fruited cultivars occurred. In "Origin of cultivated plants" published in 1886, De Candolle stated that the species Solanum melongena $\mathrm{L}$. has been known in India from ancient times and regarded this crop as a native of Asia. The versatile brinjal crop can not only be grown throughout the year but is also adapted to different agro-climatic regions. It is perennial in nature but for the purpose of vegetable it is grown commercially as an annual crop. Unripe fruits are primarily consumed as cooked vegetable in various ways and dried shoots as fuel in rural areas. Its fruits are rich in vitamins and minerals to some extent. It contains carbohydrates (4\%), protein $(1.4 \%)$, fat $(0.3 \%)$, calcium $(18 \mathrm{mg})$, phosphorus $(47 \mathrm{mg})$, iron $(0.9 \mathrm{mg})$, chlorine $(52 \mathrm{mg})$, vitamin A (124 IU), thiamine $(0.4 \mathrm{mg})$, riboflavin $(0.11 \mathrm{mg})$ and ascorbic acid $(12 \mathrm{mg})$ per $100 \mathrm{~g}$ of fresh edible part (Hazara and Som, 1999). Brinjal is not a very popular commercial vegetable of state however it is known to occupy its maximum area in the plain region rather than hills. The crop productivity of this vegetable in tarai region of state (foothills of Himalaya) is also not very much encouraging, when compared to the other parts of the country because of frequent fluctuation in climatic conditions, use of old varieties and severe crop infesta- tion by various pests. The most extensive pest of this vegetable is brinjal shoot and fruit borer (Lucinodes orbonalis Guenee) which reduces the yield and inflicts colossal loss in production. The losses caused by pest vary from season to season because moderate temperature and high humidity favour the population build-up of brinjal shoot and fruit borer (Shukla and Khatri, 2010), (Bhushan et al., 2011). This pest may reduce the crop yield up to $60-70 \%$ (Singh and Nath, 2010). To control this pest farmers use chemicals extensively which enhance cost of cultivation. Besides of this it contaminate the environment and the toxic residues remain inside the fruit generate various diseases.

Hence, in order to bring more area under brinjal cultivation and to maximize productivity along with retention of good quality fruits under the agro-climatic condition of tarai region, it has become imperative that tarai farmers should have with them some suitable new cultivars of brinjal, not only have early maturity but also have high yield potential including highest degree of disease and pest resistance. To fulfil such requirements of vegetable growers of tarai region of Uttarakhand, there is an urgent need to evaluate the yield performance of some of the newly evolved genotypes under the changing climatic condition.

\section{MATERIALS AND METHODS}

The investigation, consisted of 9 treatments including 3 checks viz., Kashi Tarun, Pant Samrat and Punjab 
Sadabahar and 6 new genotypes was carried out at Vegetable Research Centre, G.B. Pant University of Agriculture and Technology, Pantnagar, U.S. Nagar (Uttarakhand) in the autumn-winter season, 20122013. The row to row and plant to plant distance of transplants was $60 \mathrm{~cm}$ and $40 \mathrm{~cm}$, respectively. All cultural practices were followed under scientific management. The fertilizer dose of 100:50:50 kg ha-1 in the form of $\mathrm{N}: \mathrm{P}_{2} \mathrm{O}_{5}: \mathrm{K}_{2} \mathrm{O}$ was used in the investigation and two weedings were done at 39 and 53 days after transplanting. Observations for plant height, primary branches, marketable maturity, fruit length and diameter, total fruits (healthy and damaged) per plant, marketable fruits per plant, per cent fruits infested by fruit borer and marketable yield were recorded in 5 randomly selected plants. Per cent fruit infestation by fruit borer was worked out formula given below:

Per cent fruit infestation $=$ No of fruits infested by fruit borer / Total fruits $\times 100$

The data were statistically analyzed according to the analysis of Randomized Block Design as given by Gomez and Gomez (1984).

After taking into consideration the variables, fixed input and their corresponding rates, the cost incurred under each treatment was worked out on hectare basis. To get gross return/ha, the fruit yield ( $\mathrm{q} / \mathrm{ha}$ ) obtained in each treatment was multiplied with prevailing local mandi rates. Net return was calculated by deducting the cost of cultivation from the gross return and finally Benefit - Cost ratio was computed with the division of gross return by cost of cultivation

\section{RESULTS AND DISCUSSION}

Statistically, significant results were obtained for all the parameters in this study. Table-1 clearly shows that the genotypes were significantly different from each other in their plant height when measured at final harvest stage (166 DAP). Out of six genotypes and three cultivars, the plant height was recorded maximum $(76.20$ $\mathrm{cm})$ in commonly grown cultivar Pant Samrat and minimum $(64.45 \mathrm{~cm})$ in standard check Punjab Sadabahar. Statistically, the height of genotypes PB-300, PB-302 and Pant Samrat was almost at par to each other. The genotypes which were dwarf in nature were PB-301, PB-304 and Kashi Tarun. Plant height is usually a good index of plant vigour which may contribute towards greater productivity. The variation in plant height could be attributed due to differences in genetic makeup and their correlation with the existing environment as reported by Mohanty (2002). In his studies, he reported tallest brinjal plants of $105.7 \mathrm{~cm}$ and shortest of $50.30 \mathrm{~cm}$, which supports the findings of present investigation. Data depicted in Table-1 clearly also show that out of the 9 genotypes/cultivars, genotype PB-305 was produced maximum number of primary branches (9.20); however, statistically it was not different from standard checks Kashi Tarun and Punjab Sadabahar. The minimum branching (6.30) was noticed in Pant Samrat plants, however from statistics point of view, did not differ from PB-303, PB-300, PB-302, PB-304 and PB301. Similar kind of observations in brinjal cultivars were also recorded by Mohanty (2002). In his studies, the number of primary branches per plant in different genotypes was varied from 4.3 to 10.4 , as has been observed in present investigation. Days to $1^{\text {st }}$ marketable harvest was counted from the date of transplanting. On the basis of data presented in Table-1, amongst 9 genotypes/varieties Kashi Tarun and Punjab Sadabahar was registered themselves earliest maturing cultivars. These cultivars took 70 days for their $1^{\text {st }}$ harvest from the date of transplanting while Pant Samrat and PB301 had taken 80 days in their $1^{\text {st }}$ picking. On the other hand genotypes PB-300 and PB-305 were found late in their $1^{\text {st }}$ harvest by taking 103 days from the date of transplanting. Such variations in harvesting might be due to different genetic constitution of genotypes/ varieties. The table-1 also indicates that the genotypes/ cultivars were significantly different in their fruit

Table 1. Mean performance of test cultures and checks for growth and yield related traits in brinjal.

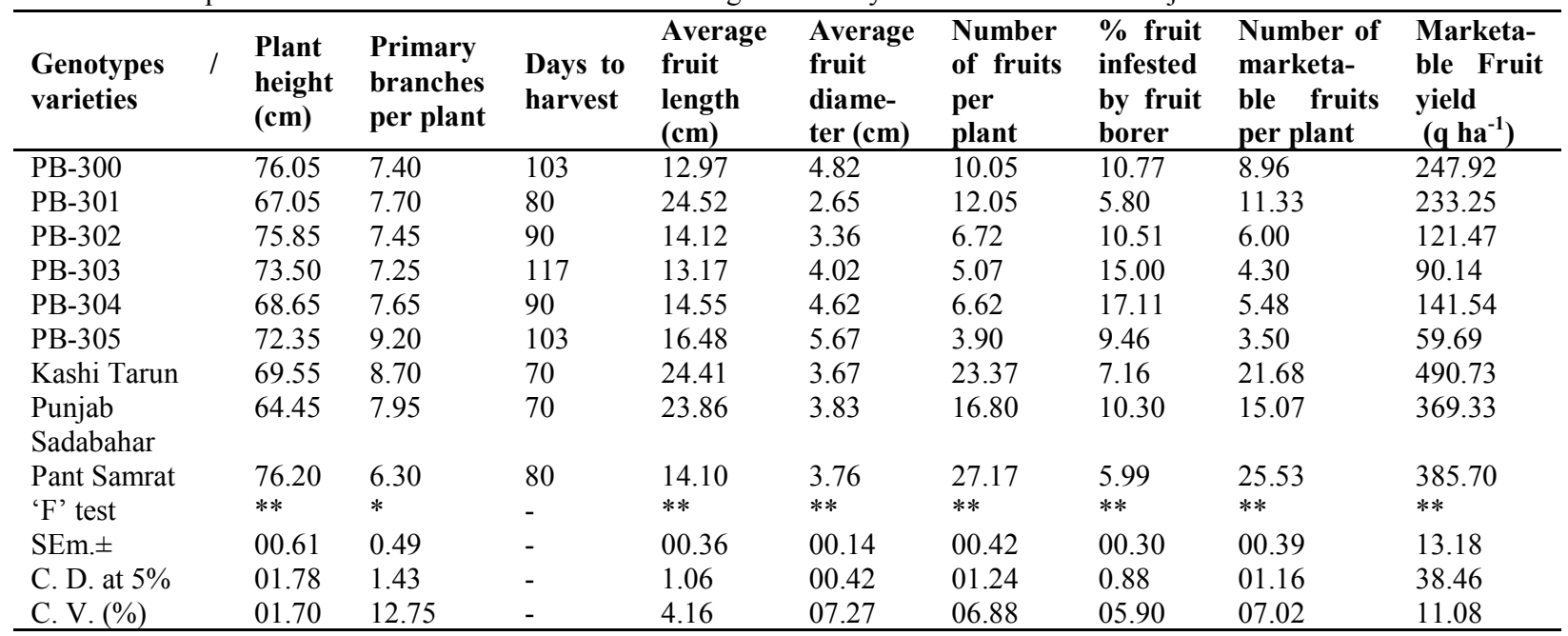


Table 2. Economics of brinjal genotypes/varieties.

\begin{tabular}{|c|c|c|c|c|c|}
\hline Genotypes & Cost of cultivation (Rs. ha ${ }^{-1}$ ) & ${ }^{*}$ Gross Return(Rs. ha $\left.{ }^{-1}\right)$ & Net Return & $\left(\right.$ Rs. ha $\left.{ }^{-1}\right)$ & B : C \\
\hline PB-300 & 95,187 & $1,23,960$ & 28,773 & & 1.30 \\
\hline PB-301 & 94,851 & $1,16,630$ & 21,779 & & 1.22 \\
\hline PB-302 & 92,299 & 60,740 & $-31,559$ & & 0.65 \\
\hline PB-303 & 91,587 & 45,070 & $-46,517$ & & 0.49 \\
\hline PB-304 & 92,755 & 70,775 & $-21,980$ & & 0.76 \\
\hline PB-305 & 90,891 & 29,850 & $-61,041$ & & 0.32 \\
\hline Kashi Tarun & $1,00,739$ & $2,45,370$ & $1,44,631$ & & 2.43 \\
\hline Punjab Sadabahar & 97,963 & $1,84,665$ & 86,702 & & 1.88 \\
\hline Pant Samrat & 98,339 & $1,92,850$ & 94,511 & & 1.96 \\
\hline
\end{tabular}

* Significant at $5 \%$ level, **Significant at $1 \%$ level

length at 119 days after transplanting ( $5^{\text {th }}$ harvest). It was measured maximum in genotype PB-301 (24.52 $\mathrm{cm})$ and minimum $(12.97 \mathrm{~cm})$ in PB-300 with a difference of $11.55 \mathrm{~cm}$. Cultivar Kashi Tarun and genotype PB-301 were statistically at par to each other in fruit length. Among commonly grown cultivars, Pant Samrat recorded minimum fruit length of $14.10 \mathrm{~cm}$. The variation in fruit length in different brinjal genotypes/cultivars reported to be inter varietal association with the genetic makeup of the cultivars and governed by the cell size and intercellular spaces of the flesh. Similar variations in fruit length of different brinjal genotypes were also reported by Babu et al. (2005). They were of the view that variation in fruit length might be due to presence of sufficient diversity among genotypes. The fruit diameter was found maximum $(5.67 \mathrm{~cm})$ in PB-305, and minimum $(2.65 \mathrm{~cm})$ in PB301. Much variation in fruit diameter was not recorded in genotypes/cultivars PB-302, Kashi Tarun and Pant Samrat. Similarly differences in fruit diameter were also not seen in Kashi Tarun, Pant Samrat \& Punjab Sadabahar. Similar to these findings, Babu et al. (2005) mentioned the highest fruit diameter $(9.10 \mathrm{~cm})$ of brinjal in genotype DBC-95-KA followed by DBC$76-\mathrm{KA}(8.66 \mathrm{~cm})$ and $\mathrm{DBC}-81-\mathrm{BI}(8.45 \mathrm{~cm})$, whereas, the genotype DBC-121-KA $(2.28 \mathrm{~cm})$ showed minimum fruit diameter of $2.28 \mathrm{~cm}$. They explained sufficient diversity among brinjal genotypes for such variation in fruit diameter. Perusal of data in Table-1 clearly shows that genotypes/varieties differed significantly from each other in respect to their fruit number per plant (healthy and infected fruits). Out of 9 genotypes/ varieties, it was cultivar Pant Samrat which produced highest number of fruits per plant (27.17) followed by Kashi Tarun (23.37) and Punjab Sadabahar (16.80). The minimum number of fruits per plant (3.90) was obtained in genotype PB-300. This study also revealed that all commercially grown varieties were superior over new genotypes in respect fruit number per plant. The above findings are in conformity to the observations made by Mohanty (2002). He reported the number of fruit per plant in genotypes were in the range of 3.6 to 22.5 and assumed this due to distinct genetic nature of genotypes.

A close examination of per cent borer infestation data in Table-1 revealed that borer infestation in 9 genotypes/varieties varied from $5.80 \%$ to $17.11 \%$. The infestation was found more in new genotypes (except PB -301) compared to commercial varieties. The least infestation was noted in PB-301 (5.80\%). The highest incidence of borer (17.11\%) was noticed in PB-304. However, borer incidence in PB-301 and Pant Samrat was statistically at par to each other. The second most susceptible genotype having $15 \%$ borer infestation was PB-303. Khuhro et al. (2011) has also reported fruit borer a serious pest of brinjal. In their studies, the pest infestation was ranged from 6.60 to $46.60 \%$ throughout the growing period. In their opinion variation in infestation could be due to arrival of brinjal fruits of different local markets. Mannan et al. (2009) and Javed et al. (2011) viewed that infestation of fruit borer in brinjal mainly varied from variety to variety. The fruits which were free from diseases and pests were considered in marketable category.

So for number of marketable fruits per plant is depicted in Table-1 clearly indicates that commercial varieties better in number of fruits per plants compared to new genotypes. Among them, Pant Samrat recorded the maximum number of marketable fruits per plant (25.53) in this study followed by Kashi Tarun (21.68) and Punjab Sadabahar (15.07). Out of six genotypes the minimum number of marketable fruits was obtained in PB-305(3.50), PB-303(4.30), and PB-304 (5.48). Patel and Sarnaik (2003) explained a good relation in number of fruits and fruit yield per plant in brinjal. They were of the view that more number of fruits per plant might be due to higher number of flower clusters per plant, and higher fruit set. It could also be due to higher number of leaves, number of branches and maximum plant spread in genotypes/cultivars.

It is also evident from Table-1 that genotypes/varieties varied significantly from each other in their marketable yield. The yield of freshly harvested fruits was obtained highest in variety Kashi Tarun (490.73 q ha ${ }^{-1}$ ) followed by Pant Samrat (385.70 q ha ${ }^{-1}$ ) and Punjab Sadabahar (369.33 q ha-1), PB-300 (247.92 q ha-1) and PB-301 (233.25 q ha ${ }^{-1}$ ). From statistical point of view the fruit yield of Pant Samrat was at par to Punjab Sadabahar. Except genotype PB-300 and PB-301, none of the genotypes could registered more than $141.50 \mathrm{q}$ 
fruit yield/ha. Potential of these two genotypes was $247.92 \mathrm{q} / \mathrm{ha}$ and $233.25 \mathrm{q} / \mathrm{ha}$, respectively. The fruit yield estimate obtained in this study is also similar to reported by Mohanty et al. (2002) in brinjal. Their findings suggest that medium sized and large number of fruits per plant will probably produce more yield than the hybrids bearing large sized fruits but few in number. Similar to this Pandit et al. (2010) also recorded significant variation in yield per plant among different genotypes of brinjal. In their experiment fruit yield was considerably reduced in summer-rainy season and the highest value was marked in genotype BCB-43 (1.36 kg/plant).

The data depicted in Table 2 clearly shows that the genotypes/varieties differed in their cost of cultivation and gross return. The highest cost of cultivation of Rs. $1,00,739 \mathrm{ha}^{-1}$ was worked out in variety Kashi Tarun followed by Pant Samrat (Rs. 98,339 ha-1), Punjab Sadabahar (97,963 ha $\mathrm{ha}^{-1}$ ) and genotype PB-300 (Rs. 95, $\left.187 \mathrm{ha}^{-1}\right)$. Similar to the cost of cultivation, the highest gross return amongst 6 genotypes and 3 varieties in present investigation was obtained in commercial cultivar Kashi Tarun (Rs. 2,45,370 ha $^{-1}$ ) followed by Pant Samrat $\left(1,92,850 \mathrm{ha}^{-1}\right)$ and Punjab Sadabahar $\left(1,84,665 \mathrm{ha}^{-1}\right)$. The maximum net return of Rs. 1,44,631.00 ha $^{-1}$ was worked out in variety Kashi Tarun followed by Pant Samrat (Rs. 94, $511.00 \mathrm{ha}^{-1}$ ). The genotypes which had shown net return in negative were PB-302, PB-303, PB-304 and PB-305. Similar to net profit, excluding genotypes PB-302, PB-303, PB304, PB-305, all other genotypes/varieties had shown higher Benefit-Cost ratio. The variety which was found best with respect to B: C ratio was Kashi Tarun (2.43), Pant Samrat (1.96) and Punjab Sadabahar (1.88). The above results with respect to profitability are in conformity with the findings of Chatterjee et al. (2011), while working on brinjal crop in west Bengal. They obtained highest net profit of Rs. 1,24,718.00 $\mathrm{ha}^{-1}$ with $\mathrm{B}: \mathrm{C}$ ratio of 2.46 .

\section{Conclusion}

Based on overall performance of different genotypes/ varieties, it could be concluded that under the prevalent climatic conditions of Uttarakhand tarai region, the existing variety Kashi Tarun is the most suited for the area. Keeping in view the higher yield potential and economy of Pant Samrat and Punjab Sadabahar these could also be included in the commercial cultivation of tarai area. However maximum resistance to fruit and shoot borer was observed in PB-301 and Pant
Samrat. These all genotypes also could also be utilized in breeding programme for yield and resistance.

\section{REFERENCES}

Babu, R. B. and Patil, R.V. (2005) Evaluation and variability studies of brinjal genotypes. Madras Agric. J. 92(7-9): 578-584.

Bhushan, S., Chaurasia, H. K. and Shanker, R. (2011). Efficacy and economics of pest management modules against brinjal shoot and fruit borer (Leucinodes orbonalis). The Bioscan. 6(4): 639-642

Chatterjee, S., Chattopadhyay, A., Dutta, S., Banerjee, A. and Hazra, P. (2011). Economics of solanaceous vegetables in the gangatic alluvial of West Bengal during autumnwinter season. Agric. Sci. Res. J. Vol. 1(9):222-227

De Candolle, A. (1986) Origin of cultivated plants. D. Appleton, New York. 500p

Gomez, K. A. and Gomez, A. A. 1984. Statistical procedures for Agriculture research (2nd edition), John Wiley and Sons, Inc., New York, pp. 357-427

Hazara, P. and Som, M. G. (1999) Technology for vegetable production and improvement. Naya Prakash, 206. Bidhan Sarani, Calcutta, India, 387p

Javed, H., Mohsin, A., Aslam, M., Naeem, M., Amjad, M. and Mahmood, T. (2011). Relationship between morphological characters of different aubergine cultivars and fruit infestation by leucinodes orbonalis guenee. Pak. J. Bot. 43(4): 2023-2028

Khuhro, S., Kanher, N. A., Shar, A. H., Mangi, S., Khuhro, R. D. and Narejo, M. U. (2011) Extent of infestation by brinjal fruit borer (Leucinodes orbonalis Guen.). Sarhad J. Agric. Vol.27, No. 3

Mannan, M. A. Begum, A. and Hossain, M. M. (2009). Screening of local and exotic brinjal varieties/ cultivars for resistance to brinjal shoot and fruit borer (Leucinodes orbonalis). Bangladesh J. Agril. Res. 34(4): 705-712

Mohanty, B. K. (2002) Variability, heritability and genetic advances studies in brinjal (Solanum melongena L.). Indian J. Agric. Res., 36(4): 290-292

Pandit, M. K., Thapa, H., Akhtar, S., Hazra, P. (2010). Evaluation of brinjal genotypes for growth and reproductive characters with seasonal variation. J. of Crop and Weed. 6 (2) 31-34

Patel, K. K. and Sarnaik, D. K. (2003) Performance study of some long fruited genotypes of brinjal under Raipur conditions. Orrisa J. Hort. 31(1): 74-77

Shukla, A. and Khatri S. N. (2010). Incidence and abundance of brinjal shoot and fruit borer Leucinodes orbonalis Guenee. The Bioscan. 5(2): 305-308

Singh, S. P. and Nath, P. (2010). Cultural and biophysical management of brinjal shoot and fruit borer (Leucinodes orbonalis). A Biannual New letter of the (CIPS) in corporation with the (IRAC) and (WRCC- 60), 20: $42-43$ 